\title{
The immanence and transcendence of God in Adamic incarnational Christology: An African ethical reflection for the public
}

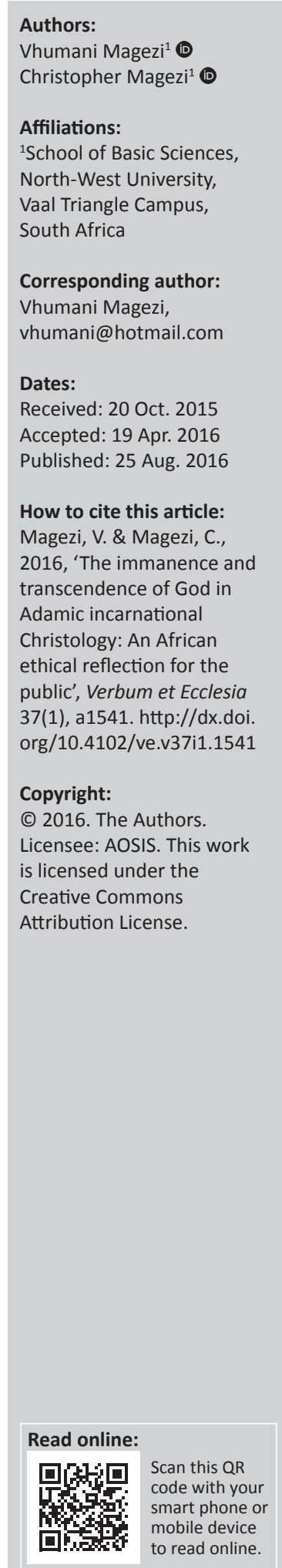

This article argues that the transcendence and immanence of God amplified in Christ should influence African believers' private and public ethics. It accomplishes this by engaging transcendence and immanence of God in the traditional African worldview. The African traditional worldview in many respects believes the transcendent God whose immanence is mediated by lesser spiritual intermediary powers. In responding to this view of God's transcendence and immanence, we discuss the amplified transcendence and immanence of God in the Adamic incarnational Christological model. This model argues that in the incarnation, God's transcendence and immanence is amplified by his assumption of our human mode of existence as the New Adam for our redemption. That is, even though God has always been transcendent and present within his creation before the incarnation, his immanence within humanity is amplified by God becoming man in and through Jesus Christ as the New Adam. The ascension of Jesus Christ does not diminish God's presence within Christians. God continues to have his personal presence within believers through the dynamic presence of the Holy Spirit among them. The transcendence and immanence of God (amplified in Christ) therefore is brought to bear in the private and public ethics of Christians. In contrast to the limited immanence of human beings, God's immanence is infinite. That is, there is nothing human beings can do which is outside of God's reach and knowledge. It is from this perspective that African Christians are encouraged to live lives conscious of the infinite-immanent God, who sees both their private and public lives. The private and public life of believers should resemble God's character and behaviour demonstrated by Jesus Christ, God incarnate, in his earthly ministry. Thus, the transcendence and immanence of God amplified in Christ influences African believers to live as the true ambassadors of Christ who exhibit exemplary ethical behaviour within the public sphere. The article reflects on the role of theological ethics in informing public ethics. As such it is theologically intradisciplinary but focusing on intertheological disciplines and their relationship to public space regarding ethics. It seeks to engage and influence public ethical behaviour in a context corruption and disregard of other human beings' entitlements.

Intradisciplinary and/or interdisciplinary implications: The article challenges the privatisation of Christianity to take a public role in order to influence the public. This approach contributes to shifting African Christians from being passive in the context of unethical behaviours to being active agents who influence the public. As such, it contributes to public, practical theology and public ethics.

\section{Introduction}

The transcendence and immanence of God are fundamental attributes of God that are closely linked together (Arseniev 1959:1). The former concept affirms God as the one who transcends space and time because he is the sole creator of everything (corporeal and incorporeal) (Horton 2011:253, cf. 253-258). The latter concept asserts God's ongoing presence within his creation while he remains distinct from it (creation) (Horton 2011). That is, God's immanence within his creation at all times and all places does not equate God with his creation as the pantheistic conception of God's presence posits (Grudem 1994:175; Horton 2011:40-41). In this way, the couplet understanding of the transcendent and immanent concepts of God affirm that God transcends both space and time as the sole originator of all things. However, his transcendence does not prohibit his direct presence within his creation (Grudem 1994:169-174). The transcendent and immanent concepts of God are part of the traditional African worldview of God, hence, it is important to understand the African view. 
This article seeks to establish how the immanence and transcendence of God amplified in Christ can influence African Christians' behaviour to mirror Christ, and therefore change society. In order to accomplish this goal, the article will initially establish Africans' conception of the transcendence and immanence of God or Supreme Being by delving into their traditional worldview of God. This will be followed by a biblical discussion of the amplified transcendence and immanence of God in Adamic incarnational Christological framework as an essential step in presenting African Christians with an alternative view of God's transcendence and immanence. The discussion will be approached mainly from a Trinitarian perspective of God (who self-revealed and self-communicated himself to humankind in the incarnation of the eternal Son of God) as one being yet three distinctive persons; namely, Father, Son and Holy Spirit. However, because of the ascension of Christ to the right hand of God the Father, the paradoxical transcendence and immanence of God through the Spirit will be established. Furthermore, in view of the nature and extent of Christ's salvation, we will argue that after God's ascension in Christ Christians are to, continue to live on this earth without conforming to its observable patterns that are covertly and overtly unethical. This is because the transcendence and immanence of God amplified in Christ should influence African Christians' behaviour and character to mirror Christ, and therefore act as agents of God in changing societies. This is possible by the empowering presence of God through the Holy Spirit, who enables Christians to function as God's ambassadors in changing societies and the world at large.

\section{The African misconception of the divine: The transcendence and immanence of God}

The traditional African concept of God's transcendence and immanence is inherent within the uniform beliefs of traditional African cultures in the interconnection between the spiritual and physical worlds (Dyrness 1990:44; Louw 2002:72; Lugira 2009:48; Mbiti 1989:74-85; Turaki 2006:34). That is, even though African scholars and theologians sometimes differ in their reference to African traditional worldview or views as a uniting concept, they concur that within the diverse beliefs of traditional African cultures, it is a common worldview thread of interconnection between the spiritual and physical worlds (Lugira 2009:48; Mbiti 1989:74-85; Turaki 2006:34). Mbiti (1989) encapsulates the interconnection between the physical and the spiritual worlds in his statement that the:

spiritual universe is united with the physical, and that these two intermingle and dovetail into each other so much that it is not easy, or even necessary, at times to draw the distinction or separate them. (p. 74)

Firstly, in various African communities, the notion of the transcendence of God is rooted in the belief that the world is occupied with impersonal mystical power, which is present in every corporeal (animate) or incorporeal (inanimate) object or place (Turaki 2006:24). In Turaki's (2006) view:
The potency, efficacy and durability of this power vary from object to object and from place to place. Some objects are inherently imputed more power than others, that is, they are assumed to be more naturally endowed with power than others are. (p. 24)

It is believed that this impersonal mystical power (associated with various kinds of natural objects such as plants, mountains, animals, etc.) can be taken and used by people through various mechanical means for either good or bad purposes in their communities (Turaki 2006:24). The evil users of this mystical power utilise it to injure other people within their societies and communities, while the good users use it to monitor or protect themselves against the evil users of this mystical power (Turaki 2006:24). Given this, in many traditional African communities, it is common to find people clothing or putting all kind of objects around their wrists, angles, waists, necks or arms as a means of protecting themselves from this impersonal mysterious power (Turaki 2006:24). In Turaki's (2006) words:

Medicine men and women, diviners and seers use the impersonal
power associated with natural objects, plants and animals for
medicine, magic, charms and amulets. Some believe that the
mysterious powers embedded in things or objects can be
extracted for specific uses. Mysterious powers can also be
transmitted through certain objects or by purely spiritual means.
They can be sent to specific destinations to accomplish good or
evil. They can also be contagious by contact with objects carrying
or mediating such powers. (p. 24 )

The impersonal powers can be used for both good and evil. The existence of wicked human beings and wicked spirit beings, who also have access to the mysterious powers, makes life full of uncertainties - rife with unpredictable wickedness and evil and dangerous to human beings. Thus, traditional Africans who believe in the impersonal powers feel that they are under the influence of those powers.

Secondly, various African cultures recognise that the spirit world is inhabited by many spirit beings (categorised as human and non-human spiritual powers) that are in a hierarchical relationship with one another (Lugira 2009:36-63; Mbiti 1989:77-80; Turaki 2006:54-66). Many scholars (cf. Agyarko 2010:52-54; Imasogie 1983:66; Lugira 2009:36; Mbiti 1989:15-77) agree that in the African concept of the spiritual world, God (Supreme Being) is the head of the hierarchy of these spiritual powers. This is because he is the sole creator of everything that exists, including the lesser spiritual entities. The lesser spiritual powers 'are thought to have been created by God. They are associated with him (God) and often stand for his activities or manifestations' in the world (Mbiti 1989:75). The fact that African people believe the Supreme Being to be the sole creator of all existing things implies that they perceive God as eternal, namely, the one who does not have a beginning or an end (Mbiti 1989:30-36). Lugira (2009:36) summarises the predominant African belief in the Supreme Being as the sole creator of everything. In this way "'most Africans" oral traditions have pointed to the existence of a power above 
which there is no other power, a Supreme Being, Creator, and Originator of the World' (Lugira 2009:36). Likewise, Mbiti (1970:45, cf. Turaki 1999:27) argues that 'our written sources indicate that practically all African peoples consider God as creator, making this the commonest attribute of the works or activities of God'.

Nevertheless, the problem emanating from the traditional African worldview is that God is not directly involved in everyday human activities, because he is transcendent and remote from the physical world (Lugira 2009:36-46; Turaki 2006:59-61). In saying this, we are aware that the transcendence of God in traditional African belief does not eliminate the concepts of God's omnipresence (his presence in all places and at all times), omniscience (his all-knowing) and omnipotence (his all-powerfulness) (Mbiti 1989:29-36). That is why:

African theologians and scholars speak about the transcendence of God, the Supreme Being, and claim that the space between God and human beings is filled with a hierarchy of gods, divinities and spirits who are sometimes called the intermediaries of God. (Turaki 2006:61)

Firstly, this belief seems to come from African traditional stories, which state that the Supreme Being has prescribed various 'duties or responsibilities' to the lesser spiritual beings interacting with the physical world (Turaki 2006:56). Secondly, it also appears to be springing from the African traditional belief that God cannot be approached directly (Dyrness 1990:48; Lugira 2009:46-48; Mbiti 1989:82; Nurnberger 2007:75; Turaki 2006:56-61).

In this way, the Supreme Being is the ultimate peak of the pyramid, but he is too remote and inaccessible to play a role in [the] practical life' of Africans (Nurnberger 2007:75). Thus, many Africans believe that:

most of the things humans need fall within the sphere of the authority of lesser spiritual beings, there is no need to go to God or bother him unless the lesser beings prove inadequate when it comes to providing powers, needs, purposes and security. (Turaki 2006:57)

Hence, inherent within the African traditional worldview is ancestral veneration, which occupies a central place in traditional African religion (Triebel 2002:193, cf. Reed \& Mtukwa 2010:148). The ancestors are those blood-related members of the family, clan or tribe, who have lived an outstanding life and who have supposedly thereby acquired supernatural powers after death, which enable them to function as both guardians and protectors of their living descendants (cf. Bediako 2004:23; Ligura 2009:48-50; Nyamiti 2006:3, 9; Oladosu 2012:160-161). The ancestors are viewed as being closer to living people than any other spiritual power, and they can either harm or bless their living descendants depending on the existing relationship between them (ancestors and the living people) (Oladosu 2012:161; Triebel 2002:187). This is why Triebel (2002) captures the centrality of ancestors in African traditional beliefs by concluding that:
Because the ancestors cause misfortune on the one hand and because on the other hand only they can grant fortune, well-being, life, and a good living - that is, fullness of life - they alone are venerated.... Therefore this cult is really the central aspect, the center of African religion. (p. 193)

However, the Africans' perception of God as a transcendent Supreme Being, who interacts with humankind through various spiritual intermediaries, seems to diminish the immanence of God in traditional African worldview. This is because even though Africans' understanding of the transcendence and immanence of God is not necessarily similar to a deistic view of God, the idea of a God who is indirectly present or involved within his creation is displayed in traditional African worldview. This (mis)conception could be taken to imply that God does not see things directly, because his presence is mediated by various spiritual intermediary powers. Possibly, this (mis)conception of God's transcendence and immanence could persist among Africans who then convert to Christianity. Some African Christians may not be conscious of the reality of God's transcendence and immanence in a way which influences their Christian public behaviour. Indeed, if one wishes African Christians to bring positive change in their African societies, 'a creative Christian engagement must answer' to this misconception of God's transcendence and immanence in traditional African worldview (Bediako 1995:99-100). Therefore, the following section will bring the perspective of the transcendence and immanence of God in the Adamic incarnational Christological framework as a step in informing some African Christians with a biblical view of God's transcendence and immanence. Following from this discussion is the following question: how can the immanence and transcendence of God amplified in Christ influence Christians' behaviour to mirror Christ and change society?

\section{The transcendence and immanence of God in the Adamic incarnational Christological model}

In response to the (mis)conception of the transcendence and immanence of God in traditional African worldview, it is important to acknowledge that Evangelical theology is grounded in the Christian doctrine of the Trinity (NkansahObrempong 2010:294). The doctrine of Trinity affirms that God is one being yet three distinctive persons, namely Father, Son and Holy Spirit (cf. Jn 14:16-17 \& Mt 28:19) (Torrance 1996:15, 1995:131). The word 'persons' in reference to the triune God does not necessarily mean that there are three 'personalities in God' (Barth 1960:403). This aforementioned understanding would result in the notion of a God who is tritheistic in nature (Barth 1960:402-403). In guarding ourselves against this potential challenge of tritheism, we argue that God is one incorporeal being (Jn 4:24), comprised of three distinctive persons without being separated or divided (Torrance 1995:110-145). We affirm the distinction between the Father, Son and Holy Spirit (but always in inseparable relationship with one another), 
which is determined by the indivisible oneness or unity in being (consubstantial) among the persons of the Godhead (Torrance 1996:169-202). The distinctive persons of the Godhead interpenetrate (perichoresis) each other, because the Father in John's (14:10) gospel is entirely in the Son and the Son is entirely in the Father (Calvin \& McNeill 1960:143; Torrance 1996:169-202). Therefore:

while the Lord Jesus Christ constitutes the pivotal centre of our knowledge of God, God's distinctive self-revelation as Holy Trinity, One Being, Three Persons, creates the overall framework within which all Christian theology is to be formulated. (Torrance 1996:2)

It is important to note that all things were created by God the eternal Father, in and through his eternal Son; and that both the continual existence and sustenance of the entire creation is dependent on the transcendent, self-existing and infinite God (cf. Heb 1:3, Col 1:15-17 \& Jn 1:3) (Barth 1966:56-58; Torrance 1981:135). In other words, Jesus Christ is the creator of all the invisible and visible things out of nothing; who lives and acts in 'lordly freedom' over his creation (Torrance 1981:4). His lordly freedom over creation as its creator, sustainer and saviour (cf. Heb 1:3) is evident in his amplified immanence within humankind in the incarnational mystery as he became flesh and dwelt among us (Jn 1:14). Here, the incarnation:

is the new act of the eternal God whereby God himself becomes man without ceasing to be God, the Creator becomes creature without ceasing to be Creator, the transcendent becomes contingent without ceasing to be transcendent, the eternal becomes time without ceasing to be eternal. (Torrance 1996:214)

Thus, in contrast to the traditional African worldview of God as the creator, whose immanence within humankind is mediated through multiple spiritual power, it is maintained that in and through Jesus Christ, God the originator of everything stepped down (from his eternal transcendent and infinite existence) into the space and time of human existence in order to save humanity. In other words, in the incarnation, God in Christ emptied himself of his honour and glory (Phlp 2:5-11) in order to have his personal presence among humanity, so that he could suffer for the sake of humanity's redemption. Therefore, the incarnation:

constitutes the one actual source and the one controlling centre of the Christian doctrine of God, for he who became man in Jesus Christ in order to be our Saviour is identical in Being and Act with God the Father. (Torrance 1996:18)

This is the one and only God who is omnipresent, omniscient and omnipotent. This implies that the transcendent and all powerful God sees all that humankind are doing, as well as knowing all that we are thinking because there is no part of his creation outside of his reach and presence.

Stated differently, the incarnation of God in Christ confronts the (mis)conception of God's transcendence and immanence in traditional African worldview with the fundamental reality that even though God is transcendent as the sole creator of everything, he is not too remote and inaccessible to play a role in the practical life of African people. This is because in Christ's incarnation, the transcendent God has once and for all moved into the bounds of space and time in order to have his personal presence among humankind as the New or Second Adam for the sake of humanity's redemption (Torrance 1992:126). This indicates that:

although God transcends time and space, he enters both freely as through an open door that he has created. More than this, even enters must be understood analogically, since God is already present in every moment and permeates every place. (Horton 2011:256)

That is, even prior to God's special immanence within his creation in and through Jesus Christ's incarnation, he (God) was both transcendent and immanent within his creation (Horton 2011:256; Zemek 1990:129-148). In Zemek's (1990:130) view, 'Psalm 113 provides a natural theological entrance into two corollary truths about God, His transcendence and His immanence'. Here, the Psalmist commands:

[a]1l men to let the praise of God resound all the world over and motivates the appeal with the declaration that this incomparable God, transcending the heavens in glory, is the Sovereign of the world who controls the affairs of men below from his throne. (Zemek 1990:137-138)

However, even though God has been always present within his creation (as its sustainer) before the incarnational mystery of Jesus Christ (cf. Ps 113), it is apparent that in Jesus Christ, God's special personal presence within humanity is amplified by his assumption of our human mode of existence as the New Adam (cf. Rm 5:12-21; 1 Cor 15:21-22) (Barth 1956:9-10; Torrance 2008:73). In this case, an understanding of the vicarious humanity of Christ as determined by the anhypostastic and enhypostastic principles is vital in deepening African believers' understanding of God's personal immanence within humankind as amplified in Christ (Barth 1958:49; Gunton 1992:47; Moltmann 1974:231; Torrance \& Walker 2008:230). An anhypostatic union states that the human nature of Christ is without an independent centre of personhood, because it finds its centre or expression in the eternal person of the Son of God (enhypostastic union) (Torrance \& Walker 2008:84, 229, 2009:1xxiii). Indeed, if the human nature of Christ does not have its own independent expression, and that this lies instead in eternal Word, this makes room for the reality that the Word, the Creator, assumed a common Adamic human nature, not merely a discrete one. In other words, the couplet significance of anhypostasia and enhypostasia brings to the forefront the reality that in the incarnation, God in Christ was immanent within all humankind as the New Adam, because his human nature embraces all humankind, regardless of their tribal, national or genealogical categories (Bavinck 2006:306). Given this, 'the salvation of the world lies in the fact, that Transcendent God became Man, became near to me and like me, and that we are now "grafted" on Him' (Arseniev 1959:10).

The above understanding can be summarised as the Adamic incarnational Christological framework, which is substantiated by the view that salvation in Jesus Christ is the 'reversal of 
Adam's fall' (Dunn 1989:105; cf. Jewett 2013:80-82; Schreiner 1998:275). Scripture presents an Adamic Christology by drawing comparisons between Adam and Christ, either explicitly (cf. Rm 5:12-21; 1 Cor 15:21-22, 45-49) or implicitly (cf. Lk 3-4; Heb 2:5-18). In the comparisons between Adam and Christ, there is an ontological inclusivity of all mankind in their vicarious humanity. Here, Adam stands as the head of the fallen humanity, while Christ stands as the head of the redeemed humanity. Also, Adam is a type of Christ who is the real thing (the anti-type) which the type symbolises (cf. Rm 5:14) (Barth 1956:9-10, cf. Hultgren 2011:226). That is, even though there are continuities between Adam and Christ on the basis of the corporate solidarity of humankind in their vicarious humanity; the God-man, Jesus Christ transcends Adam in all respects as the one who 'undoes' Adam's sin and death for all humankind who believe in his saving person and work ( $\mathrm{Rm} \mathrm{5:12-21).} \mathrm{Therefore,} \mathrm{in} \mathrm{the} \mathrm{incarnational}$ mystery, the transcendent God is personally immanent within humankind as the New Adam (Jesus Christ) for the sake of our redemption. That is to say:

within this human-inhuman existence of Adam, Jesus Christ comes as the Son of God, the Son of man as Jesus calls himself, to live out a truly obedient and filial, that is a truly human life, in perfect and unbroken union with God the Father ... In all of that Jesus Christ is the last Adam, the one who...brings to an end the bondage of Adam's sin, breaks its power and opens up a new and living way to God. (Torrance \& Walker 2008:73)

However, this does not mean that the Evangelical doctrine of the incarnation has never been contested in Christian history. Hick (1993) challenged the orthodox doctrine of incarnation. He challenged Barth (1956:346) as the representative voice of Evangelical theology in their claim of Christianity as the only true means of salvation, because of the uniqueness of the incarnation of Christ, the eternal Son of God (Barth 1956:346). For this reason, Hick (1993:ix) de-constructed the Orthodox Christian doctrine of Christ's incarnation. In order to parallel Christianity with non-Christian religions, Hick (1993:ix) argues that the incarnation of the Divine Logos should be understood in a metaphorical sense. That is, 'Jesus embodied, the ideal of a human life lived in faithful response to God... and he accordingly embodied a love which is a human reflection of the divine love' (Hick 1987:21). In this way, Hick denies Jesus' claim (in Jn 10:30 \& Jn 14:9) to be in one being with the Father (Hick 1995:53). He argues that these words were put in Jesus' mouth 60 or 70 years after Jesus' death by the Scriptural authors, who expressed their ideas which were developed during the expansion of the early Church (Hick 1995:53). However, Hick's serious weakness is his presumptuous claim to know Jesus better than the disciples, who knew him directly and were closer to him.

In conclusion, the traditional African worldview is continually confronted by the fact that God does not engage with humankind through various spiritual intermediaries. Instead, in his special-personal presence, God in the incarnation dwelt among us as the New Adam and saved us from sin and all its consequences so that we can live godly lives which brings honour and glory to him (cf. 1 Pt 2:9-12).
This is the godly life which resembles God's behaviour and character amplified in his immanence in Christ. The underlying reality is that:

Christ, through whom we return into favour with God, has been set forth before us as our example, whose pattern we ought to express in our life ... we must take care that God's glory shines through us, and must not commit anything to defile ourselves with the filthiness of $\sin$ (1 Corinthians 3, 16, 6:19 \& 2 Corinthians 6:16). (Calvin 1960:686-687)

This is because the incarnation of the Son of God:

was not the bringing into being of a created intermediary between God and man, but the incarnating of God in such a way that in Jesus Christ he is both God and man in the fullest and proper sense. (Torrance 1995:150)

\section{The paradoxical transcendence and immanence of God in our New Adam's ascension}

In Barth's (1956:23) view, 'the resurrection and the ascension (of Christ) is the main stay of everything' in the New Testament. However, the ascension of Christ confronts Christians with the paradoxical notion of the transcendence and immanence of God. This paradox is captured in Farrow's notion of the continuity and discontinuity between the present world and the world to come (Farrow 1999:46). In his book Ascension and Ecclesia, Farrow (1999:40\&43) encapsulates this existing paradox of God's remoteness and nearness after Christ's ascension by delineating the existence of two histories in Scripture, namely, world history and covenant history. In the wider argument of his book, Farrow contends that through Jesus' ascension, world history and covenant history are now separated to our view, although world history is still ultimately determined by the covenant history. Concerning the covenant history, Torrance and Walker (2009:294) is in line with Farrow by the contention that the ascension of Christ is the ultimate end of creation and redemption revealed in the covenant of grace and fulfilled in Jesus Christ'. In other words, covenant history has 'already reached its goal' in Christ's ascension, and yet it is now out of our sight in heaven where Christ is seated at the right hand of God the Father (Farrow 1999:40). However, world history continues in this present era of Christianity, and believers are to continue to live in this world history without conforming to its observable sinful patterns (Farrow 1999:43).

Nevertheless, the ascension of Christ does not necessarily mean that God is distant from us because he has ascended into heaven where he is seated at the right hand of God the Father. Instead, as African believers continue to live in this interim period of Christianity, we affirm that God continues to have his complete presence or immanence within all Christians through the dynamic presence of the Holy Spirit in their lives. In arguing for God's real and ongoing presence within African believers through the dynamic presence of the Holy Spirit, we are closing a gap between the transcendence and immanence of God after 
Christ's ascension. That is, even though God in our New Adam (Jesus Christ) is absent from believers in the sense of his physical appearance, nonetheless, through the dynamic presence of the Holy Spirit, he continues to have real presence with them. In saying this, we have the same conviction as Torrance and Walker (2009) state that:

It is through the Spirit that things infinitely disconnected disconnected by the 'distance' of the ascension - are nevertheless infinitely closely related. Through the Spirit, Christ is nearer to us than we are to ourselves, and we who live and dwell on earth are yet made to sit with Christ in heavenly places, partaking of the divine nature in him. (p. 294)

This is why Luke and John emphasise that the man Jesus Christ (our New Adam), the very God himself, is the one who gives the Spirit to those who are so deeply related to him as brothers (cf. Heb 2:5-18) and friends given to him by the Father (cf. Jn 10:29). In Luke, it is the ascended Jesus of Nazareth who sends the Spirit (Lk 24:36-49; Ac 1:2-4 \& 2:4). In John, it is the resurrected man Jesus who breathes into his disciples his Spirit (Jn 20:22). The truth is that when Christians have Jesus by faith, they have full assurance and full security that they have the Holy Spirit. This is against certain neo-Pentecostal claims that the gift and possession of the Holy Spirit is to be doubted without further experiences. That is, we ought to agree with Torrance (1992) that in the early Church of the New Testament:

when the crucified Jesus rose again from the dead and poured out his Spirit at Pentecost, the intrinsic significance of his person and all he had said and done broke forth in its self-evidencing power and seized hold of the church as the very Word or Logos of God. (p. 4)

Given this, in view of the transcendence and immanence of God after Christ's ascension, one should maintain that the triune God does not plant African believers in eternal union and participation with himself (in the Son and through the Holy Spirit) and abandon them (Fee 1994:8; Murray 1998:141). Instead, the eternal Son of God came into our fallen world and adorned flesh as the New Adam in order to vicariously overcome the corruption that came through the first Adam and have a direct victory over evil. Victorious, he now indwells African Christians by the Spirit (cf. 1 Cor 6:19-20) and secures them in his inaugurated kingdom of righteousness as they await the kingdom's consummation (Fee 1994:8; Murray 1998:141).

\section{Towards an ethical reflection of the transcendence and immanence of God for African Christians}

Kandiah (2015:1) in Christian Today observed that the Church is growing slowest in Europe and North America and fastest in Africa. He reported that the growth of the African Church in particular is jaw-dropping.

In 1900 there were fewer than 9 million Christians in Africa. Now there are more than 541 million. In the last 15 years alone, the Church in Africa has seen a 51\% increase, which works out on average at around 33000 people either becoming Christians or being born into Christian families each day in Africa alone.

On the other hand, while the dawn of democracy across the African continent brought hope and promise to many people, this hope is increasingly being eroded by corruption, oppression and much unethical behaviour of public office bearers. Transparency International Perception Index (2014:9), an index that measures the perceived levels of public sector corruption worldwide (100 - being very clean and 0 - being highly corrupt) indicate that all African countries have a less than 50 points except Botswana with 63, and ranked 31 in the world. This is followed by Namibia and Rwanda with 49 points and ranked 55 in the world. Global average score is 43 whereas sub-Saharan Africa is 33 . Worryingly, $92 \%$ of sub-Saharan African countries scored below 50 points. Nussbaum (2003:1) observed that African political leaders have betrayed their fundamental humanness. Macheka (2014:1) added his voice that African leaders have embraced corruption and departed from the cherished values and ideals aspired for post-colonial Africa. Masango (2002:707) echoed the same concerns as Macheka that the world views African leaders as plagued by corruption, dictatorship and many other bad governance practices. Jones (2015:6) describes the effects of corruption and unethical behaviour. He explained that corruption undermines democracy and good governance, it violates human rights, it distorts markets and it erodes quality of life. Corruption and unethical behaviour destroys people and abandons moral principles as well as norms of social justice.

Juxtaposing the above depressing African situation and the growth of Christianity prompts one to ask the question: why is there no positive relationship between growth of Christianity and resultant values with the level of corruption and unethical behaviour? Although this question is outside the scope of this discussion, it provides a pointing perspective to our discussion. Pugh (2004:1) commenting on the Christian Welsh revival (1904-1905) and its leader, Evan Roberts, stated that it was abundantly clear that without the practical, courageous, and persistent application of the Christian ethic to every phase of human life, however trivial and ordinary, no person could even begin to call himself a Christian. One of the leading authorities on the Sociology of Religion, Rodney Stark (1996), in his book The Rise of Christianity, records a somewhat similar situation in a telling account of how Christianity grew in the first four centuries from an obscure, marginal Jesus movement to be a dominant religious movement deriving from its practices and ethos. This clearly illustrates the influence that Christianity and Christians should have in public life and behaviour in shaping society ethically, among other things.

However, the rampant corruption in African leadership has proved the African notion of Ubuntu to be a failure in acting as an instrument for unselfish leadership in Africa. The African concept of Ubuntu denotes the essence of 
being human in African traditional terms (Tutu 1999:31-32). In African traditional way, Ubuntu refers to 'generous, hospitable, friendly, caring and compassionate' people (Tutu 1999:31-32). However, the aforesaid corruption in African leadership fails to reflect the Ubuntu concept. The level of corruption in African leadership tends to connote African leaders and public office bearers as uncaring, unhospitable and uncompassionate. African leaders and public office bearers are benefitting illegally from money which is sometimes aimed to serve the poor and the marginalised within their various societies and communities. Now, is that hospitable, caring, friendly, compassionate and generous? The answer to this question is an emphatic no! Maybe this is why Matolino and Kwindingwi (2013:200) and Eliastam (2015:2) indirectly indicate that the concept of Ubuntu can be manipulated to serve the interests of individuals, which complicates our understanding of the concept of Ubuntu. Given this, Magezi (2015:3) similarly sustains that 'Ubuntu is an outdated notion that does not change people's ethics to curb corruption and injustice'. The concept of Ubuntu has limited influence in African countries and societies because the qualities (such as hospitality, generosity, caring, etc.) associated with the concept are normally referred 'to people bound geographically and relationally' (Magezi 2015:3). In other words, the concept of Ubuntu is reminiscent of the inclusion and exclusion of other people depending on the coexisting relationships and the geographical locations. As a result, discrimination and corruption are ongoing challenges within various African nations and societies. Thus, Magezi (2015) sharply criticises the Ubuntu concept in his argument that:

One other major concern raised against the current view of Ubuntu is its exclusiveness. Ubuntu's definition of community narrowly refers to people bound geographically and relationally. Ubuntu tends to exclude people who do not come from the same geographical area (ethnicity) or not filially related. (p. 3)

Moreover, in taking the traditional African cultures seriously, Bujo (2001:xiv) has attempted to construct a moral tradition which is comprised of African traditional materials. The reason for this ethical construction is that Bujo views African traditional ethics as sharing some similarities with Christian ethics. He states that African ethics is communal in nature because it revolves around a relational structure which involves people (including the living, dead and the unborn children), the cosmos and God (Bujo 2001:1-6, 65). Bujo (2001) argues that:

... hospitality, daily friendship, and dialogue with the members of other ethnic groups are vital laws from which no one is excepted. One who is not a member of my own group is ultimately also the 'property' of the other just as I myself am, and this means that I owe him respect and esteem. Thus, one is ultimately related to all human beings. (pp. 5-6)

Thus, in Bujo's view:

Recognition of relatedness is important for proper appreciation of how Africans make moral judgments. African ethics ... is concerned with the significance of the community for the discernment and lying down of norms and for ethical conduct as a whole. This sense of relatedness goes beyond the concrete visible community to embrace the dead as well. (Ikechukwu 2008:591)

It is within this (Bujo's) framework of interpersonal network that love, hospitality, friendships and dialogue take place beyond tribal and ethnic boundaries (Bujo 2001:5-6). However, Bujo's view that African communities comprise hospitality and friendship which they extend towards other African ethnic groups is contested from history (Ikechukwu 2008:595). History does not view African communities as receptive and hospitable of each other. In the past, Africa has witnessed ethnic conflicts among different ethnic groups (Ikechukwu 2008:595). In Ikechukwu (2008) understanding, these historical conflicts include:

... the Nigerian pogrom of 1966, the Liberian/Sierra Leonean massacres, the Hutu/Tutsi genocides, and all, and all other such cases show, one common factor in all of them is the question of ethnic superiority and the unwillingness to confer equality on some people who are not of one's own family or stock. (p. 595)

In spite of the criticism facing Bujo's ethical dimensions, the fact that his Christian ethics resonates with the traditional African concept of communality, is noted and granted. However, the question is: what is the contribution of Bujo's ethical construction in the contemporary Africa, in which Christianity in Africa is reported as rapidly growing more than in any other continent, yet the practical lives of Africans are not changing (Kandiah 2015:1). Maybe this is why Magezi (2015:8, cf. Bowers 2009; Gifford 2008 are of the same opinion) in maintaining their view that African Christianity requires a fresh way that engages and challenges ongoing bad public practices and ills. Current African Christian thinking and reflection is deficient in addressing emerging challenges in the modern and technologically advanced Africa (Bowers 2009; Gifford 2008).

In view of the above, one can argue that the evident rate of corruption in African leadership reflects lack of accountability and little desire to act in public interest. Accountability is a challenge because people conduct themselves differently in their private and public spaces. This means that even though we can put human structures in place to influence people to act responsibly, the challenge remains that structures are always limited in bringing change and accountability among people in private and public spaces. Worse, structures do not address people's consciences. Therefore, this makes it imperative to fashion and construct theologies that arouse a sense of accountability and responsibility for individuals to conduct their various duties and obligations in a responsible, accountable and trustworthy manner in public or private spaces.

Now, the Christian worldview of the transcendence and immanence of God may arguably influence African believers to live as the true ambassadors of Christ in their private and public lives. This is because it challenges the traditional African concept of God, which views God's presence within his creation as mediated through various spiritual powers. The Adamic incarnational Christological model presented 
in the transcendence and immanence of God in the Adamic incarnational Christological model heading argues that God had always been directly present within his creation before the incarnation; however, his presence within humanity is amplified by God's assumption of our human nature in and through Jesus Christ as the New Adam. That is, before and after the incarnation, God's immanence within his creation was not mediated by various spiritual powers inherent in the traditional African worldview. God has been always directly present within his creation as its creator and sustainer before he assumed our human mode of existence. In saying this, we are moving towards the assertion that God's transcendence and immanence amplified in Christ should be brought to bear in the private and public behaviour of African Christians. This is because a correct understanding of these two interrelated attributes of God (the transcendence and immanence of God) can enable African Christians to be more cognisant of God's direct presence within his creation.

This above-mentioned Christian understanding of the transcendence and immanence of God has an important implication for the ethics of believers. The ethical implication arises from the fact that the transcendent and immanent God sees all that humankind are doing, as well as knowing all that we are thinking, because there is no part of his creation outside of his reach and knowledge (Jr 23:23-32). That is to say, God is omnipresent; therefore, he sees directly everything we do as part of his creation. In this way, the immanence of God amplified in Christ challenges Christians to live lives which correspond to their sanctified status in Christ because God sees us directly. Thus, people cannot have private and public behaviours such as stealing, committing adultery, gossiping and so on. For instance, even though one can embezzle state funds because he or she cannot be seen by other people, the immanence of God challenges them to be more conscious of the fact that God sees both their private and public life because there is nothing hidden from him. In saying this, we call African Christians not to live lives which are influenced by the fear and respect of other people as reverence of God. They should conduct themselves in a way worthy of their new life in Christ because they respect the infinite God who is directly present in every place and sees everything they do. To encapsulate this, although the presence of humanity is limited to a particular location in time, the opposite is true of God who has unlimited presence within his creation. This is why Psalm 139 calls our private and public ethics to be governed by the omnipresent God, who is all-knowing and all-seeing. In this Psalm, there is no place where King David could go where the omniscient and omnipresent God is not a permanent reality.

The notion of the transcendence and immanence of God corresponds with the actuality that God will hold all people accountable for their good and evil deeds they perform during their earthly lives. That is, when Christ appears to judge the living and the dead in his parousia, all people will be held accountable for the good and evil deeds they did (2 Cor 5:10) during their lifetime. The point that God will hold humankind accountable for their ethical behaviour during their lifetime qualifies the direct immanence of God within his creation. This is the God who sees everything we do in our private and public lives. Even though African Christians continue to live in this interim Christian period in which God is paradoxically transcendent and immanent in Christ's ascension, they should live exemplary lives (Rm 5:12, 12:2; 1 Pt 2:11b). They should practically live lives and conduct that correspond to their new status in Christ (Eph 6:16), the New Adam. The transformational aspect ( $\operatorname{Rm~12:2)~of~the~minds~of~believers~is~purposed~for~}$ their realization and discernment of God's will in all facets of their lives, so that they can live Christlike lives within their societies (Kruse 2012:465-466).

Likewise, in reconsidering Paul's juxtaposition of indicative and imperative ( $\mathrm{Rm}$ 6:1-14) in light of Pauline Apocalypticism, Tsui (2013:313) calls Christians' behaviours and actions to be shaped by 'the apocalyptic vision of the new life in Christ, which the indicative conveys, captures believers into the reign of Christ characterized by freedom and serves as the locus whereby Paul articulates the imperative that subsequently guides believers' actions'. Here, Paul's command for the believers in Romans 6:12-13 is to correctly befit their new sanctified status in Christ (Tsui 2013:297-314). Hence, in applying Romans 12:1-2 and 6:1-14 to African Christians, one should be correct to advise Christians to develop functional Christ-like character in changing their societies. In commanding believers to change societies by their Christ-like behaviour and character, we remind Christians that God's empowering presence is with them through the Spirit. This is because:

We are not left on our own as far as our relationship with God is concerned; neither are we left on our own to 'slug it out in the trenches', as it were, with regard to the Christian life. Life in the present is empowered by the God who dwells among us and in us. As the personal presence of God, the Spirit is not merely some 'force' or 'influence'. The living God is a God of power and by his Spirit the power of the living God is present with and for us. ... The Spirit also empowers for endurance in the midst of adversity (Col. 1:11, 2 Cor. 12:9-10) and for everything else as we endure, awaiting the final glory, of which the Spirit is the guarantee. (Fee 1994:8)

That is, through the dynamic presence of the Spirit in believers' lives, God enables African Christians to act as change agents to the rest of society. They should transform societies they live:

[a] model of the kind of godly life the Father wants to see in every Christian. He who was God in the flesh was able to manifest the kind of holiness of character in his attitudes, behaviours, and interpersonal relationships that provided a concrete example of the moral image of God that he wanted to see restored in fallen man. Jesus became a demonstration of holiness with a human face, and by so doing became a model of life and character for everyone desiring to be remade in the image of the Holy One of the universe. (Coppedge 1980:93) 
The underlying reality is that by being partakers of God's ethical values in Christ, believers become the representatives or ambassadors of God in their daily lives (cf. 2 Cor 5:20) (Coppedge 1980:83; Nelson 2011:65; Wright 2010:246). Christians are responsible for their performance and character, because they are representing the incarnated and ascended God, Jesus Christ. Thus, God's work of changing the world is not divorced from the agent work of believers (as the light of the world) as his partners to bring about that universal restoration, as Wright (2010:246) correctly observes: 'God's work of rescuing, restorative justice must happen in us in order that it can happen through us'.

\section{Conclusion}

This article argued that even though the self-existing and infinite God is transcendent, his transcendence does not eliminate his direct presence with his creation. Here, we challenged the traditional African worldview misconception of the transcendence and immanence of God. This is the misapprehension of God as a transcendent Supreme Being, who interacts with humankind through various spiritual intermediaries. By commencing from the Evangelical Trinitarian doctrine of God as one being yet three distinctive persons, we affirmed that in the incarnation, in and through Jesus Christ, God has his personal presence within us as our New Adam (cf. Rm 5:12-21 \& 1 Cor 15). That is, even though the transcendent God has been always present within his creation since the beginning of creation as its creator and sustainer, his immanence within creation is amplified in the incarnational mystery, in which he became man for salvation of humanity. The ascension of Christ at the right hand of God does not undermine the continuity of God's personal presence within believers. Scripture assures Christians that there is an ongoing personal presence of God within them through the indwelling by the Holy Spirit. We further argued that the aspect of the transcendence and immanence of God amplified in Christ has huge implications for Christian ethics that should extend to society. The transcendent God who sees our entire private and public life is always present within his creation without being confined to a specific location as finite humankind is. This understanding should inform African Christians to live as the true ambassadors of God in their private and public ethics because the transcendent God sees and knows everything. In other words, God is not like finite human beings who are only present in a particular space in time. That is, there is nothing outside of God's reach and knowledge.

\section{Acknowledgements \\ Competing interests}

The authors declare that they have no financial or personal relationships which may have inappropriately influenced them in writing this article.

\section{Authors' contributions}

V.M. conceptualised the article and its outline including formulating the core research ideas and theme. C.M. mined the data and conducted preliminary data analysis. Both the authors engaged in writing, editing and critical review and refining of the article for its completion.

\section{References}

Agyarko, O. R., 2010, God of Life: Rethinking the Akan Christian Concept of God in the Light of the Ecological Crisis, Ecumenical review 65(1), 51-66.

Arseniev, N.S., 1959, 'Transcendence and immanence of God', St Vladimir's Seminary Quarterly 3(4), 2-10.

Barth, K., 1956, Christ and Adam - Man and humanity in Romans 5, Oliver \& Boyd, Edinburgh.

Barth, K., 1958, The doctrine of reconciliation: Church dogmatics, Vol. IV, 1, transl. G.W. Bromiley \& T.F. Torrance, T. \& T. Clark, Edinburgh

Barth, K., 1960, The doctrine of the Word of God: Church dogmatics, Vol. I, 1, transl. G.T. Thomson, T. \& T. Clark, Edinburgh.

Barth, K., 1966, Dogmatics in outline, transl. G.T. Thomson, SCM Press, London.

Bavinck, H., 2006, Sin and salvation in Christ: Reformed dogmatics, Vol. 3, Baker Academic, Grand Rapids, MI.

Bediako, K., 1995, Christianity in Africa: The renewal of a Non-Western Religion, University Press, Edinburgh.

Bediako, K., 2004, Jesus and the gospel in Africa: History and experience, Orbis Book, New York.

Bowers, P., 2009, 'Christian Intellectual Responsibilities in Modern Africa', Africa Journal of Evangelical Theology 28, 91-114.

Bujo, B., 2001, Foundation of an African ethic: Beyond the universal claims of Western morality, transl. B. McNeil, Crossroad, New York.

Calvin, J., 1960, Institutes of the Christian Religion 1, Westminster Press, Philadelphia, PA.

Coppedge, A., 1980, 'Holiness and discipleship', Wesleyan Theological Journal 15(2), $80-97$.

Dunn, J., 1989, Christology in the making: A New Testament inquiry into the origins of the incarnation, 2nd edn., William B. Eerdmans, Grand Rapids, MI.

Dyrness, W.A., 1990, Learning about theology from the third world, Zondervan, Grand Rapids, MI.

Eliastam, J.L.B., 2015, 'Exploring Ubuntu discourse in South Africa: Loss, Liminality and Hope', Verbum et Ecclesia 36(2), Art. \#1427. http://dx.doi.org/10.4102/ve. v36i2.1427

Farrow, D., 1999, Ascension and Ecclesia: On the significance of the doctrine of the Ascension for Ecclesiology and Christian Cosmology, William B. Eerdmans, Grand Rapids, MI.

Fee, G.D., 1994, God's empowering presence: The Holy Spirit in the letters of Paul, Hendrickson Publishers, Peabody, MA.

Gifford, P., 2008, 'Africa's inculturation Theology: Observations of an outsider', Hekima Review 38, 18-34.

Grudem, W., 1994, Systematic Theology: An introduction to Biblical Doctrine, InterVarsity Press, Nottingham.

Gunton, C.E., 1992, Christ and creation, William B. Eerdmans, Grand Rapids, MI.

Hick, J., 1987, The myth of Christian uniqueness, SCM Press Ltd, Maryknoll, NY.

Hick, J., 1993, The metaphor of God incarnate, SCM Press Ltd, London.

Hick, J., 1995, 'A Pluralistic view', in S.N. Gundry, D.N. Okholm \& R.T. Phillips (eds.), Four views on salvation in a Pluralistic world, pp. 29-59, Zondervan, Grand Rapids, MI.

Horton, M., 2011, Christian faith: A systematic theology for pilgrimage on the way Zondervan, Zondervan.

Hultgren, A.J., 2011, Paul's letter to the Romans: A commentary, William B. Eerdmans, Grand Rapids, MI.

Igué, J.O., 2010, 'A new generation of leaders in Africa: What issues do they face?', International Development Policy 1. http://dx.doi.org/10.4000/poldev.139, viewed 12 April 2016, from http://poldev.revues.org/139

Ikechukwu, O.P., 2008, 'An African moral theology of inculturation. Methodological considerations', Theological studies 69(3), 593-609.

Imasogie, O., 1983, Guidelines for Christian theology in Africa, Achimota, Africa Christian Press, Ghana.

Jewett, R., 2013, Romans: A short commentary, Fortress Press, Minneapolis, MN.

Jones, G., 2015, The vicious cycle of corruption, Accountable leadership and sustainability in Africa, Abstracts- UNISA, 21-24th April.

Kandiah, K., 2015, The Church is growing, and here are the figures that prove it, Christian Today, viewed 20 October 2015, from http://www.christiantoday.com

Kruse, C.G., 2012, Paul's letter to the Romans, William B. Eerdmans, Grand Rapids, MI.

Louw, D.J., 2002, 'A practical theological ecclesiological of relocalisation and globalisation from below: Towards a viable African Renaissance', Journal of Theology for Southern Africa 112, 69-87.

Lugira, A.M., 2009, World Religions: African traditional religion, Third Edition, Chelsea House Publishers, New York. 
Macheka, M.T., 2014, 'An evaluation of post-colonial African leadership: A study of Ayi Kwei Armahs the Beautiful Ones Are Not Yet Born, and Chinua Achebes A Man of the People', International Journal of English and Literature 5(1), 14-18.

Magezi, V., 2015, 'Ubuntu in flames - Injustice and disillusionment in post-colonial Africa: A practical theology for new "liminal Ubuntu" and personhood", A paper presented at the international Academy of Practical Theology, University of Pretoria, Pretoria, South Africa.

Masango, M., 2002, 'Leadership in the African continent', Verbum Et Ecclesia JRG 23(3), 707-718.

Matolino, B. \& Kwindingwi, W., 2013, 'The End of Ubuntu', South African Journal of Philosophy 32(2), 197-205.

Mbiti, J., 1970, Concepts of God in Africa, SPCK, London.

Mbiti, J., 1989, African Religions and Philosophy, Heinemann, London.

Moltmann, J., 1974, The crucified God, SCM Press, London.

Murray, J., 1998, Holy in Christ. A devotional look at your life, Christian focus, Fearn.

Nelson, P.K., 2011, 'Discipleship dissonance: Toward a theology of imperfection amidst the pursuit of holiness', Journal of Spiritual formation \& Soul Care 4(1) 63-92.

Nkansah-Obrempong, J., 2010, 'Evangelical theology in Africa: Ways, perspectives, and Dilemmas', Evangelical Review of Theology 34(4), 293-299.

Nurnberger, K., 2007, The living dead and the living God: Christ and the ancestors in changing Africa, C B Powell Bible Centre, Pretoria.

Nussbaum B., 2003, 'African culture and Ubuntu', Perspectives 17(1), 1-12.

Nyamiti, C., 2006, Studies in African Christian Theology, Vol. 2, Jesus Christ, the Ancestor of Humankind: An essay on African Christianity, CUEA Publications, Nairobi.

Oladosu, O.A., 2012, 'Ancestral veneration in the religious expression of the indigenous Aladura Churches', Ogbomoso Journal of Theology XVII(2), 159-171.

Pugh, C., 2004, The Welsh Revival of 1904-1905, viewed 20 October 2015, from http://www.welshrevival.org/histories/pugh/04.htm

Reed, R. \& Mtukwa, G., 2010, 'Christ our ancestor: African Christology and the danger of contextualization', Wesleyan Theological Journal 45(1), 144-163.
Schreiner, T., 1998, Romans: Baker exegetical commentary in the New Testament, Baker Academic, Grand Rapids, MI.

Stark, R., 1996, The rise of Christianity: How the obscure, Marginal Jesus movement became the dominant religious force in the Western world in a few centuries, Princeton University Press, Princeton, NJ.

Torrance, T.F., 1981, Divine and contingent order, Oxford University Press, Oxford.

Torrance, T.F., 1992, The mediation of Christ, W.B. Eerdmans, Grand Rapids, MI.

Torrance, T.F., 1995, The Trinitarian faith, T \& T Clark, Edinburgh.

Torrance, T.F., 1996, The Christian Doctrine of God: One being three persons, T \& T Clark, Edinburgh.

Torrance, T.F., 2008, Incarnation: The person and life of Christ, IVP Academic, Downers Grove, IL.

Torrance, T.F., 2009, Atonement: The person and work of Christ, IVP Academic, Downers Grove, IL.

Transparency International, Corruption Perceptions Index 2014, viewed 20 October 2015, from http://www.transparency.org

Triebel, J., 2002, 'Living together with the ancestors: Ancestor veneration in Africa as a challenge or missiology', Missiology: An International Review XXX(2), 187-197.

Tsui, T.K., 2013, 'Reconsidering Pauline Juxtaposition of indicative and imperative (Romans 6:1-14) in light of Pauline Apocalypticism', Catholic Biblical Quarterly Journal 75, 297-314.

Turaki, Y., 1999, Christianity and the African Gods. A Method in Theology, Potchefstroom University, Potchefstroom.

Turaki, Y., 2006, Foundations of African traditional religion and world-view, Word Alive Publishers, Nairobi.

Tutu, D., 1999, No future without forgiveness, Random House, New York, pp. 31-32.

Wright, N.T., 2010, After you believe. Why Christian character matters, HarperOne, New York.

Zemek, G.J., 1990, ‘Grandeur and Grace: God's transcendence and immanence in Psalms 113', The Masters Seminary Journal 1(2), 129-148. 